Table 1. Radiation Inactivation of ImMUNologicai and BIOlogical AcTivities OF HCQ

\begin{tabular}{|c|c|c|c|}
\hline Assay & $\begin{array}{c}D_{89} \times 10^{-6} \mathrm{rads} \\
(95 \% \text { limits })\end{array}$ & $\begin{array}{l}\text { Target volume-m } \mu^{8} \\
(95 \% \text { limits })\end{array}$ & $\begin{array}{l}\text { Mol. wt. } \times 10^{-} \\
(95 \% \text { limits })\end{array}$ \\
\hline $\begin{array}{l}\text { Biological } \\
\text { Prostate }\end{array}$ & & & \\
\hline weight & $(23 \cdot 10-28 \cdot 91)$ & $(28.57-36.36)$ & $(23 \cdot 7-30 \cdot 1)$ \\
\hline $\begin{array}{l}\text { Testes } \\
\text { weight }\end{array}$ & 25.63 & 32.54 & $\begin{array}{c}27 \cdot 0 \\
(23 \cdot 8-30 \cdot 1)\end{array}$ \\
\hline Immunological & $(23 \cdot 12-$ & $(28.74-)$ & \\
\hline Hæmagghutination & $63 \cdot 01$ & $12 \cdot 90$ & $10 \cdot 7$ \\
\hline Radioimmunoassay & $\begin{array}{l}58 \cdot 31 \\
(50.63-68 \cdot 74)\end{array}$ & $\begin{array}{c}14 \cdot 01 \\
(11.76-16.28)\end{array}$ & $\begin{array}{c}11 \cdot 6 \\
(9 \cdot 8-13 \cdot 5)\end{array}$ \\
\hline
\end{tabular}

The radiation dose required to reduce activity to $36 \cdot 8$ per cent $\left(D_{37}\right)$ as measured biologically by prostate weight response was $25.67 \times 10^{6} \mathrm{rads}\left( \pm 1.29 \times 10^{6}\right.$ (S.E.M.)) and as measured by testes weight response was $25 \cdot 63 \times$ $10^{6}$ rads $\left( \pm 1.26 \times 10^{6}\right)$. The $D_{37}$ measured by hæmagglutination inhibition was $63.01 \times 10^{6}$ rads $( \pm 2.09 \times$ $10^{6}$ ) and by radioimmunoassay was $58.31 \times 10^{6}$ rads $\left( \pm 4.27 \times 10^{8}\right)$. The target volume calculated ${ }^{1}$ from biological data averaged $32.5 \mathrm{~m} \mu^{3}$. The target volume calculated from immunological data averaged $13.5 \mathrm{~m} \mu^{3}$. Assuming a density of 1.376 g/c.c. the molecular weight calculated from biological data was $27.0 \times$ $10^{3}$, which agrees well with previous physical measurements ${ }^{9}$. The molecular weight calculated from immunological data was $11 \cdot 2 \times 10^{3}$.

These findings are interpreted as demonstrating that the structural unit required for immunological activity of HCG is considerably smaller than the unit required for biological activity.

William E. PaUl* William D. Odeli $\dagger$

Endocrinology Branch,

National Cancer Institute,

Bethesda 14, Maryland.

* Clinical associate, Endocrinology Branch, National Cancer Institute. † Senior investigator, Endocrinology Branch, National Cancer Institute.

${ }^{1}$ Lea, D. E., Actions of Radiations on Living Cells, second ed. (Cambridge Univ. Press, 1955).

' Nydick, M., Berry, R. and Odell, W. (in the press).

${ }^{3}$ Wide, L., Acta Endrocrin., 41, Supple. 70 (1962).

4 Diczfalisy, E., Hösberg, B., and Westman, A., Acta Endocrin., 5, 226 (1950).

${ }^{5}$ McArthur, J., Endocrinology, 50, 304 (1952).

${ }^{6}$ Boyden, S. V., J. Exp. Med., 93, 107 (1951).

${ }^{7}$ Feinberg, R., Fed. Proc., 13, 493 (1954).

${ }^{8}$ Skom, J. H., and TaImage, D. W., J. Clin. Invest., 37, 783 (1958).

${ }^{9}$ Gôt, R., doctoral thesis, Univ. Paris, (1959).

\section{Origin of Neuraminic Acid in Human Seminal Fluid}

THE occurrence and possible function of the neuraminic acids in mammalian tissues and fluids is a matter of great interest. Large amounts of $N$-acetylneuraminic acid have been demonstrated in the seminal fluid of $\operatorname{man}^{1,2}$, bull ${ }^{3}$ and boar ${ }^{4}$. Analysis of the secretions of the accessory genital organs of the boar showed that the mucin from the bulbourethral glands contained 4-4.5 per cent (fresh weight) of neuraminic acid. The conemtration was less in the seminal vesicles and negligible in the other glandular secretions ${ }^{5}$. In man the average concentration of neuraminic acid was in the seminal vesicle fluids $231.9 \mathrm{mg} /$ $100 \mathrm{ml}$., in the prostatic secretions $60.6 \mathrm{mg} / 100 \mathrm{ml}$., and in the seminal fluid $124 \cdot 2 \mathrm{mg} / 100 \mathrm{ml}$. From these data, Warren ${ }^{2}$ calculated that approximately two-thirds of the seminal fluid came from the prostate gland. It is, however, difficult to calculate the relative contribution of the various glandular systems to the ejaculate by using data obtained from extracts of autopsy material.

It is known that during ejaculation the three main glandular systems contributing to the ejaculate are discharged successively. The first portion comes from the prostate gland, the second from the testes and epididymis, and the third from the seminal vesicles. During ejacula- tion the secretions from these three glandular systems become more or less mixed. By estimating the concentration of acid phosphates (from the prostate gland), spermatozoa (from the testes, epididymis and vas deferens) and fructose (from the seminal vesicles) in each portion of a 'split-ejaculate' it is possible to calculate the amount secreted by each of these glandular systems ${ }^{6}$.

In the prosent investigation the origin of neuraminic acid was examined by analysing each portion of splitejaculates for its content of acid phosphatase, fructose and neuraminic acid. The procedure and analytical methods have been described earlier ${ }^{6,7}$. Neuraminic acid was determined by the thiobarbituric acid method ${ }^{3}$. The various seminal fractions were not examined for their content of spermatozoa since the secretions of the testes, epididymis and ductus deferens are relatively small and probably add little to the neuraminic acid content of the semen ${ }^{2,6}$. Analysis of the sperm cells by the Ehrlich or resorcinol test showed the presence of only very small amounts of neuraminic acid ${ }^{2}$. Seminal fluid was received from five healthy male volunteers aged $25-30$.

The analytical data from a typical experiment is presented in Fig. 1. The results indicate that neuraminic acid is secreted in nearly equal amounts from both the prostate gland and the seminal vesicles. This secretory pattern is not usual since most substances investigated are secreted mainly or entirely from a single gland.

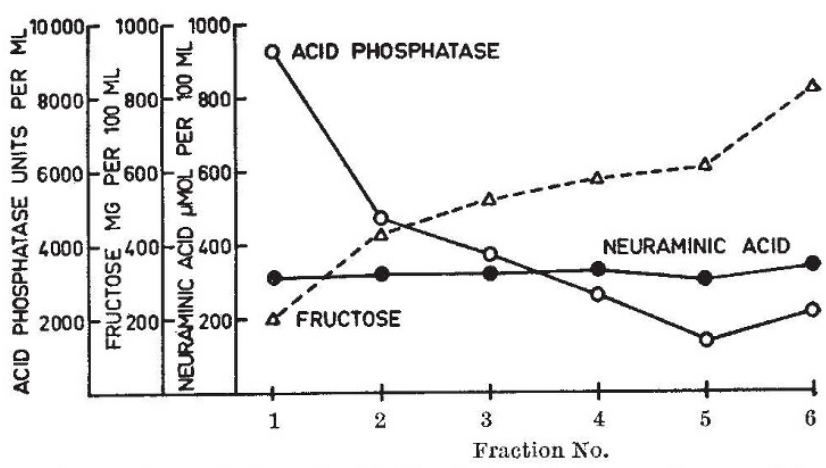

Fig. 1. Concentration of acid phosphatase, fructose and neuraminic 'split-ejaculation method'

The highest concentration found in the seminal vesicle secretions (last fractions) was $430 \mu$ moles $/ 100 \mathrm{ml}$. This is lower than the mean value $(750 \mu$ moles $/ 100 \mathrm{ml}$.) given by Warren ${ }^{2}$ for the seminal vesicle fluid obtainad at autopsy. Moreover, the mean value given by Warren $^{2}$ for the prostatic fluid (196 $\mu$ moles $/ 100 \mathrm{ml}$.) is below the concentrations found in the first fractions of the ejaculates (250-350 umoles $/ 100 \mathrm{ml}$.).

The concentration of neuraminic acid in the total ejaculates varied between 200 and $350 \mu$ moles $/ 100 \mathrm{ml}$. This is in the same order of magnitude as found by Svennerholm ${ }^{1}$ and Warren ${ }^{2}$.

The significance of neuraminic acid for human fertility is not known, but work on this problem is in progress.

This work was supported by the Swedish Medical Research Council and the Population Council, New York. Crystalline $N$-acetylneuraminic acid was kindly supplied by Dr. L. Svennerholm, Gothenburg.

Department of Physiology,

Rune Eliasson

Faculty of Medicine, Karolinska Institutet, Stockholm.

${ }^{1}$ Svennerholm, L., Acta Chem. Scand., 12, 547 (1958),

2 Warren, I. J. Clin. Invest., 38, 755 (1959).

3 Warren, L., J. Biol. Chem., 234, 1971 (1959).

¿ Odin, L., Acta Chem. Scand., 9, 1234 (1955).

5 Hartree, E. F., Nature, 196, 483 (1962).

' Lundquist, F., Acta Physiol. Scand., 19, Supp. 66 (1949).

7 Fliasson, R., Acta Physiol. Scand., 46, Supp. 158, 12 (1959). 